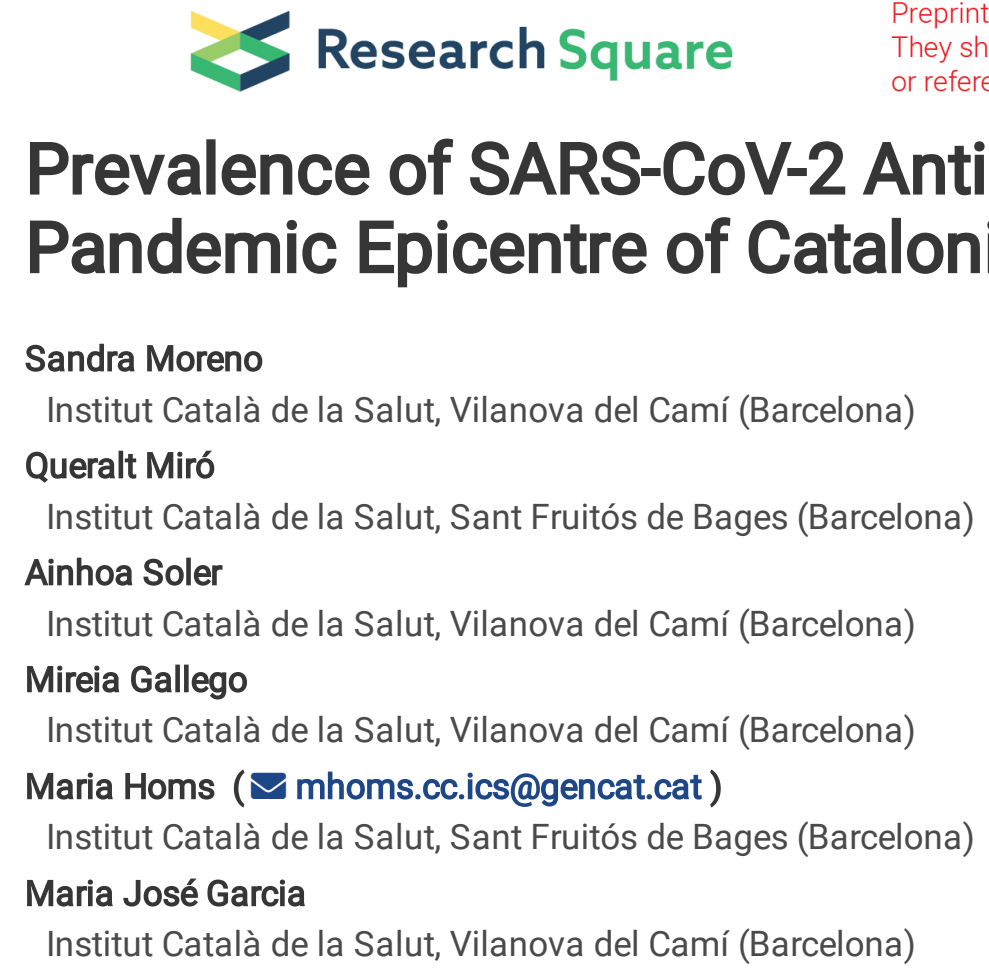

\author{
Sandra Moreno \\ Institut Català de la Salut, Vilanova del Camí (Barcelona) \\ Queralt Miró \\ Institut Català de la Salut, Sant Fruitós de Bages (Barcelona) \\ Ainhoa Soler \\ Institut Català de la Salut, Vilanova del Camí (Barcelona) \\ Mireia Gallego \\ Institut Català de la Salut, Vilanova del Camí (Barcelona) \\ Maria Homs ( $\nabla$ mhoms.cc.ics@gencat.cat) \\ Institut Català de la Salut, Sant Fruitós de Bages (Barcelona) \\ Maria José Garcia \\ Institut Català de la Salut, Vilanova del Camí (Barcelona)
}

\title{
Prevalence of SARS-CoV-2 Antibodies and Risk Factors in the Pandemic Epicentre of Catalonia
}

\section{Research Article}

Keywords: SARS-CoV-2 seroprevalence, antibodies, AMG, socio-economic index, obesity

Posted Date: January 10th, 2022

DOI: https://doi.org/10.21203/rs.3.rs-1199770/v1

License: (c) (i) This work is licensed under a Creative Commons Attribution 4.0 International License. Read Full License 


\section{Abstract}

Aim To define the seroprevalence of antibodies against SARS-CoV-2 in the municipality of Vilanova del Camí (in the subregion of Conca d'Ódena) and to know the risk factors associated with positive seroprevalence.

Method Cross-sectional descriptive study. The population of Vilanova del Camí had the opportunity to voluntarily attend two screenings for antibodies against SARS-CoV-2 (October and December 2020). Users who participated in the screening signed an informed consent form. From the 3610 attendees at the screening 2,170 patients were randomly selected. The test results and other demographic variables (sex, age, morbidity index) and users' clinical variables (diagnoses, smoking and drugs) were analysed.

Results The prevalence of antibodies against COVID19 was $9.6 \%$ (95\% Cl 8.4\% to 10.9\%) and was similar for men and women but increased with age. In complex chronic patients, the prevalence was $14.3 \%$ and in patients with advanced chronic disease, 25\%. Age, AMG (Adjusted Morbidity Groups) index, COVID diagnosis and COVID contact diagnosis were risk factors for positive seroprevalence. The October analysis detected a higher seroprevalence (12.16\%) than in the December analysis (8.38\%). In the December screening, obesity was a risk factor for positive seroprevalence.

Conclusions This study demonstrates the high seroprevalence of antibodies in the pandemic epicentre of Catalonia. The differences in the analysis of October and December show the impact of the first wave in the Conca d'Ódena sub-region.

\section{Introduction}

Coronavirus acute respiratory syndrome 2 (SARS-CoV-2) was identified in December 2019 as the cause of COVID-19 ${ }^{1}$. On March 11, 2020, the World Health Organization (WHO) declared a pandemic for COVID-19². The Spanish Government approved a Royal Decree (RD 463/2020 of 14 March) to establish a state of alarm to manage the health crisis. Over the past year, successive decrees have been passed to establish measures aimed at minimising population mobility and the spread of the virus.

In March 2020, Conca d'Ódena was considered the national pandemic epicentre, implying a strict confinement from March 12 to April $6,2020^{3}$. Conca d'Ódena is formed by the grouping of several municipalities in the province of Barcelona, in the region of Anoia: Igualada, Vilanova del Camí, Santa Margarida de Montbui and Ódena. It is estimated that $40 \%$ of health professionals in the Conca were Covid cases or contacts during the month of March, although there are no official published data. At the beginning of the pandemic, no diagnostic tests were available and many of the possible cases were suspected cases of COVID-19 without antigenic confirmation.

Spain is one of the European countries most severely affected by the pandemic ${ }^{4}$. Up to March 2021, the accumulated incidence at the state level amounted to 4,967,200 cases and in Catalonia 912,546 cases, of which 86,621 have died in the state and 15,494 have died in Catalonia. In Anoia County from 01/03/2020 to 24/03/2021, 7460 cases were detected and 618 deaths due to COVID-19 were registered. Although it is recognized that the territory of Conca d'Ódena suffered severely from the impact of COVID-19 during the first wave, the percentage of the population with antibodies against COVID-19 at that time is unknown and we will never know the number of real cases because diagnostic tests were not available at the beginning.

Seroprevalence studies quantify the proportion of the population that has antibodies against a pathogen. Most SARS-CoV-2 seroprevalence studies detect IgG-type antibodies ${ }^{5}$. Several seroprevalence studies have been published worldwide ${ }^{6-10}$. The Spanish study published in The Lancet, ENE-COVID ${ }^{11}$, analysed more than 61,000 randomly selected individuals between April 27 and May 11, 2020 using immunochromatography and chemiluminescence tests. In this study a seroprevalence of $5 \%$ was established in the Spanish state and, in the province of Barcelona, a seroprevalence of $7 \%$ was established. The study detected differences between provinces and ages, but no gender differences ${ }^{11}$. An Italian seroprevalence study found a higher prevalence of antibodies in women than in $\operatorname{men}^{12}$. 
The risk factors for the disease are unknown, although some associated with positive seroprevalence have been established. The main ones are: being a contact of a positive case ${ }^{13}$ and being a health worker ${ }^{14}$. In the Dutch population, $2.7 \%$ of antibodies were found to be present and the following risk factors were detected: the Protestant religious community and the use of immunosuppressants, antivirals or antibiotics in the last month ${ }^{15}$.

According to the report of the ISCIII Coronavirus Scientific Analysis Group (GACC-*ISCIII) ${ }^{16}$ COVID-19 does not affect everyone equally. The incidence and severity of the disease is related to the presence of chronic diseases. Comorbidities could explain some of the differences according to gender and age. Possible risk factors associated with COVID-19 include: diabetes mellitus, chronic respiratory disease, chronic renal failure, cancer, immunosuppression, obesity, cardiovascular disease and smoking ${ }^{16}$.

The objective of this study was to define the seroprevalence of antibodies against SARS-CoV-2 in the municipality of Vilanova del Camí (Conca d'Ódena) in the first and second wave of COVID. To analyse seroprevalence according to age groups, gender, adjusted morbidity groups index (AMG), country of origin, Complex Chronic Patient (CCP) and Advanced Chronic Disease (ACD) status and comorbidities.

\section{Results}

In this study, 2,170 patients were analysed, with a median age of 47 years and $59 \%$ women. Of the total number of users, $1 \%$ were CCP and $0.2 \%$ ACD. The migrant population attending screening represented $1.6 \%$, and there were $38.8 \%$ of users with a AMG of $2,22.7 \%$ with a AMG of 3 and $5.0 \%$ with a AMG of 4 (Table 1 ). 
Table 1

Characteristics of the total population, the first screening and the second screening.

\begin{tabular}{|c|c|c|c|c|}
\hline & $\begin{array}{l}\text { Total } \\
(\mathrm{N}=2,170)\end{array}$ & $\begin{array}{l}\text { 1st Screening } \\
(n=691)\end{array}$ & $\begin{array}{l}\text { 2nd Screening } \\
(n=1.479)\end{array}$ & p-value \\
\hline Women & $1281(59.03)$ & $417(60.3 \%)$ & $864(58.4 \%)$ & 0.421 \\
\hline $\mathrm{Age}^{\star}$ & $47.4(20.09)$ & $47.21(20.98)$ & $48.27(19.65)$ & \\
\hline Age group & & & & 0.078 \\
\hline under 20 years old & 255 (11.75) & $97(14.0 \%)$ & $158(10.7 \%)$ & \\
\hline 20-39 years old & 403 (18.57) & $129(18.7 \%)$ & $274(18.5 \%)$ & \\
\hline $40-59$ years old & $842(38.80)$ & $248(35.9 \%)$ & $594(40.2 \%)$ & \\
\hline 60 years of age or older & $670(30.87)$ & $217(31.4 \%)$ & $453(30.6 \%)$ & \\
\hline Number of diagnoses & & & & 0,216 \\
\hline None & 1107 (51.06) & $337(48.9 \%)$ & $770(52.1 \%)$ & \\
\hline 1 & $595(27.44)$ & $195(28.3 \%)$ & $400(27.0 \%)$ & \\
\hline 2 & $252(11.62)$ & $77(11.2 \%)$ & $175(11.8 \%)$ & \\
\hline 3 or more & $214(9.87)$ & $80(11.6 \%)$ & $134(9.06 \%)$ & \\
\hline CCP & $21(0.97)$ & $13(1.88 \%)$ & $8(0.54 \%)$ & 0.006 \\
\hline ACD & $4(0.18)$ & $2(0.29 \%)$ & $2(0.14 \%)$ & 0.596 \\
\hline Migrants & $32(1.63)$ & $7(1.10 \%)$ & $25(1.89 \%)$ & 0.271 \\
\hline AMG & & & & 0.105 \\
\hline 1 & 709 (33.28) & $207(30.5 \%)$ & $502(34.6 \%)$ & \\
\hline 2 & $827(38.83)$ & $272(40.1 \%)$ & $555(38.2 \%)$ & \\
\hline 3 & $487(22.86)$ & $156(23.0 \%)$ & $331(22.8 \%)$ & \\
\hline 4 & $107(5.02)$ & $43(6.34 \%)$ & $64(4.41 \%)$ & \\
\hline COVID diagnosis (previous $6 \mathrm{~m}$ ) & $123(5.67)$ & $78(11.3 \%)$ & $45(3.04 \%)$ & $<0.001$ \\
\hline Contact COVID (previous 6m) & $233(10.74)$ & $60(8.68 \%)$ & $173(11.7 \%)$ & 0.042 \\
\hline Cancer & $387(17.83)$ & $143(20.7 \%)$ & $244(16.5 \%)$ & 0.020 \\
\hline Cardiopathy & $35(1.61)$ & $15(2.17 \%)$ & $20(1.35 \%)$ & 0.220 \\
\hline DM & $194(8.94)$ & $65(9.41 \%)$ & $129(8.72 \%)$ & 0.660 \\
\hline HTA & $459(21.15)$ & $159(23.0 \%)$ & $300(20.3 \%)$ & 0.164 \\
\hline Kidney Failure & $76(3.5)$ & $27(3.91 \%)$ & $49(3.31 \%)$ & 0.564 \\
\hline Obesity & $527(24.29)$ & $173(25.0 \%)$ & $354(23.9 \%)$ & 0.615 \\
\hline Respiratory Disease & $154(7.1)$ & $51(7.38 \%)$ & $103(6.96 \%)$ & 0.793 \\
\hline
\end{tabular}

The p-value expresses the comparison between the first and second screening population.

*The mean and standard deviation were used to describe the variable age. 


\begin{tabular}{|lllll|}
\hline & $\begin{array}{l}\text { Total } \\
\mathbf{( N = 2 , 1 7 0 )}\end{array}$ & $\begin{array}{l}\text { 1st Screening } \\
\mathbf{( n = 6 9 1 )}\end{array}$ & $\begin{array}{l}\text { 2nd Screening } \\
(\mathbf{n = 1 . 4 7 9 )}\end{array}$ & p-value \\
\hline Smoking Diagnosis & $356(\mathbf{1 6 . 4 1 )}$ & $105(15.2 \%)$ & $251(17.0 \%)$ & 0.328 \\
\hline Prescription Antibiotics & $195(8.99)$ & $73(10.6 \%)$ & $122(8.25 \%)$ & 0.094 \\
\hline Prescription Antivirals & $9(0.41)$ & $3(0.43 \%)$ & $6(0.41 \%)$ & 1.000 \\
\hline Prescription immunosuppressants & $14(0.65)$ & $4(0.58 \%)$ & $10(0.68 \%)$ & 1.000 \\
\hline The p-value expresses the comparison between the first and second screening population. \\
\hline *The mean and standard deviation were used to describe the variable age. \\
\hline
\end{tabular}

Just under half of the users had one or more diagnoses. The diagnoses detected were obesity (24.3\%), cancer (17.8\%), type II diabetes (8.9\%), respiratory disease (7.10\%), renal failure (3.5\%) and heart disease $(1.6 \%)$. Of the possible risk factors described, smoking (16.4\%), prescription of antibiotics (8.9\%), antivirals $(0.4 \%)$ and immunosuppressants $(0.6 \%)$ one month prior to the test were analysed (Table 1).

A total of $5.7 \%$ of the population analysed had a diagnosis of COVID in the 6 months prior to testing and $10.7 \%$ had a diagnosis of close contact COVID in the 6 months prior to testing (Table 1).

The prevalence of antibodies against COVID19 detected in the population analysed was $9.6 \%$, with a $95 \% \mathrm{Cl}$ of $8.4-10.9 \%$. By sex, the prevalence was similar between men and women, $9.2 \%$ and $10.1 \%$ respectively ( $p$-value $=0.525)$. The seroprevalence of antibodies increased with age (Figure 1 ) and this increase was significant in the older age group ( $p$-value $=0.008$ ): in children under 20 years of age, the prevalence was $8.2 \%$, in those aged 20 to 39 years $8.2 \%$, in those aged 40 to 59 years $8.1 \%$ and in those over 59 years, the prevalence was $12.8 \%$ (Table 2). In CCP, the prevalence was $14.3 \%$ and in ACD, 25\%. 
Table 2

Prevalence and prevalence ratio of the variables analysed, in the total sample and in the first and second screening.

\begin{tabular}{|c|c|c|c|c|c|c|c|c|c|}
\hline & Total & PR & $\begin{array}{l}\mathrm{P} \text { - } \\
\text { value }\end{array}$ & $\begin{array}{l}\text { 1st } \\
\text { Screening }\end{array}$ & PR & $\begin{array}{l}\mathrm{P} \text { - } \\
\text { value }\end{array}$ & $\begin{array}{l}\text { 2nd } \\
\text { Screening }\end{array}$ & PR & $\begin{array}{l}\mathrm{P} \text { - } \\
\text { value }\end{array}$ \\
\hline Total sample & $\begin{array}{l}208 \\
(9.58)\end{array}$ & $\begin{array}{l}(8.42 ; \\
10.89)\end{array}$ & & $84(12.16)$ & $\begin{array}{l}(9.93 \\
14.80)\end{array}$ & & $\begin{array}{l}124 \\
(8.38)\end{array}$ & $\begin{array}{l}(7.01 ; \\
9.91)\end{array}$ & \\
\hline Females & $\begin{array}{l}118 \\
(9.21)\end{array}$ & $\begin{array}{l}0.91 \\
(0.70 \\
1.18)\end{array}$ & 0.525 & $49(11.8)$ & $\begin{array}{l}0.92 \\
(0.61 ; \\
1.38)\end{array}$ & 0.776 & 69 (7.99) & $\begin{array}{l}0.89 \\
(0.64 ; \\
1.25)\end{array}$ & 0.576 \\
\hline Age group & & & 0.008 & & & 0.705 & & & 0.003 \\
\hline Under 20 & $\begin{array}{l}21 \\
(8.23)\end{array}$ & Ref & & $11 c(11,34)$ & Ref & & 10 (6.33) & Ref & \\
\hline Between 20 and 39 & $\begin{array}{l}33 \\
(8.19)\end{array}$ & $\begin{array}{l}0.99 \\
(0.58 \\
1.74)\end{array}$ & & $17(13.17)$ & $\begin{array}{l}1.16 \\
(0.55 \\
2.56)\end{array}$ & & $16(5.84)$ & $\begin{array}{l}0.92 \\
(0.42 ; \\
2.10)\end{array}$ & \\
\hline Between 40 and 59 & $\begin{array}{l}68 \\
(8.08)\end{array}$ & $\begin{array}{l}0.98 \\
(0.61 ; \\
1.64)\end{array}$ & & $26(10.48)$ & $\begin{array}{l}0.92 \\
(0.47 \\
1.95)\end{array}$ & & $42(7.07)$ & $\begin{array}{l}1.12 \\
(0.58 \\
2.36)\end{array}$ & \\
\hline $\begin{array}{l}60 \text { years of age or } \\
\text { older }\end{array}$ & $\begin{array}{l}86 \\
(12.83)\end{array}$ & $\begin{array}{l}1.56 \\
(0.99 \\
2.57)\end{array}$ & & 30 (13.82) & $\begin{array}{l}1.22 \\
(0.63 \\
2.54)\end{array}$ & & $\begin{array}{l}56 \\
(12.36)\end{array}$ & $\begin{array}{l}1.95 \\
(1.04 ; \\
4.07)\end{array}$ & \\
\hline Diagnostics & & & 0.765 & & & 0.939 & & & \\
\hline None & $\begin{array}{l}100 \\
(9.03)\end{array}$ & Ref & & $43(12.76)$ & Ref & & $57(7.40)$ & Ref & 0.421 \\
\hline 1 & $\begin{array}{l}59 \\
(9.91)\end{array}$ & $\begin{array}{l}1.09 \\
(0.79 \\
1.51)\end{array}$ & & $24(12.31)$ & $\begin{array}{l}0.96 \\
(0.58 \\
1.57)\end{array}$ & & 35 (8.75) & $\begin{array}{l}1.18 \\
\text { (0.77; } \\
1.79)\end{array}$ & \\
\hline 2 & $\begin{array}{l}25 \\
(9.92)\end{array}$ & $\begin{array}{l}1.09 \\
(0.69 \\
1.67)\end{array}$ & & $8(10.39)$ & $\begin{array}{l}0.81 \\
(0.35 \\
1.64)\end{array}$ & & $17(9.71)$ & $\begin{array}{l}1.31 \\
(0.74 ; \\
2.20)\end{array}$ & \\
\hline 3 or more & $\begin{array}{l}24 \\
(11.21)\end{array}$ & $\begin{array}{l}1.24 \\
(0.78 \\
1.90)\end{array}$ & & $9(11.25)$ & $\begin{array}{l}0.88 \\
(0.40 \\
1.72)\end{array}$ & & $\begin{array}{l}15 \\
(11.19)\end{array}$ & $\begin{array}{l}1.51 \\
(0.82 \\
2.59)\end{array}$ & \\
\hline $\mathrm{CCP}$ & $\begin{array}{l}3 \\
(14.29)\end{array}$ & $\begin{array}{l}1.50 \\
(0.52 ; \\
4.30)\end{array}$ & 0.446 & $2(15.4)$ & $\begin{array}{l}1.27 \\
(0.35 \\
4.63)\end{array}$ & 0.665 & $1(12.5)$ & $\begin{array}{l}1.49 \\
(0.24 \\
9.42)\end{array}$ & 0.504 \\
\hline ACD & $\begin{array}{l}1 \\
(25.00)\end{array}$ & $\begin{array}{l}2.62 \\
(0.48 ; \\
14.35)\end{array}$ & 0.332 & $1(50.0)$ & $\begin{array}{l}4.15 \\
(1.02 ; \\
16.84)\end{array}$ & 0.228 & $0(0.0)$ & - & 1 \\
\hline Origin & & & 0.129 & & & 0.605 & & & 0.018 \\
\hline Native & $\begin{array}{l}190 \\
(9.85)\end{array}$ & Ref & & 79 (12.5) & Ref & & $\begin{array}{l}111 \\
(8.55)\end{array}$ & Ref & \\
\hline Migrant & $\begin{array}{l}6 \\
(18.75)\end{array}$ & $\begin{array}{l}1.90 \\
(0.91 ; \\
3.97)\end{array}$ & & $0(0.0)$ & - & & $6(24.00)$ & $\begin{array}{l}2.81 \\
(1.37 ; \\
5.77)\end{array}$ & \\
\hline AMG & & & 0.043 & & & 0.435 & & & 0.095 \\
\hline
\end{tabular}

* They are represented by $\mathrm{n}$ and percentages.

The reference category for comparison has been the No condition. 


\begin{tabular}{|c|c|c|c|c|c|c|c|c|c|}
\hline & Total & PR & $\begin{array}{l}\mathrm{P}- \\
\text { value }\end{array}$ & $\begin{array}{l}\text { 1st } \\
\text { Screening }\end{array}$ & PR & $\begin{array}{l}\mathrm{P} \text { - } \\
\text { value }\end{array}$ & $\begin{array}{l}\text { 2nd } \\
\text { Screening }\end{array}$ & PR & $\begin{array}{l}\text { P- } \\
\text { value }\end{array}$ \\
\hline 1 & $\begin{array}{l}52 \\
(7.33)\end{array}$ & Ref & & $19(9.17)$ & Ref & & $33(6.57)$ & Ref & \\
\hline 2 & $\begin{array}{l}84 \\
(10.16)\end{array}$ & $\begin{array}{l}1.38 \\
(0.98 \\
1.97)\end{array}$ & & $38(13.97)$ & $\begin{array}{l}1.52 \\
(0.89 \\
2.69)\end{array}$ & & $46(8.29)$ & $\begin{array}{l}1.26 \\
(0.81 \\
1.98)\end{array}$ & \\
\hline 3 & $\begin{array}{l}54 \\
(11.09)\end{array}$ & $\begin{array}{l}1.51 \\
(1.03 \\
2.22)\end{array}$ & & $20(12.82)$ & $\begin{array}{l}1.39 \\
(0.74 \\
2.63)\end{array}$ & & $\begin{array}{l}34 \\
(10.27)\end{array}$ & $\begin{array}{l}1.56 \\
(0.97 \\
2.53)\end{array}$ & \\
\hline 4 & $\begin{array}{l}15 \\
(14.02)\end{array}$ & $\begin{array}{l}1.91 \\
(1.04 \\
3.31)\end{array}$ & & $6(13.95)$ & $\begin{array}{l}1.52 \\
(0.55 \\
3.59)\end{array}$ & & $9(14.06)$ & $\begin{array}{l}2.14 \\
(0.96 \\
4.28)\end{array}$ & \\
\hline Covid Diagnostics & $\begin{array}{l}104 \\
(84.55)\end{array}$ & $\begin{array}{l}16.64 \\
(13.60 ; \\
20.37)\end{array}$ & $<0.001$ & $75(96.15)$ & $\begin{array}{l}65.49 \\
(34.19 \\
125.45)\end{array}$ & $<0.001$ & $\begin{array}{l}29 \\
(64.44)\end{array}$ & $\begin{array}{l}9.73 \\
(7.27 \\
13.02)\end{array}$ & $<0.001$ \\
\hline Contact COVID & $\begin{array}{l}32 \\
(13.73)\end{array}$ & $\begin{array}{l}1.51 \\
(1.06 \\
2.15)\end{array}$ & 0.031 & $7(11.7)$ & $\begin{array}{l}0.96 \\
(0.46 \\
1.98)\end{array}$ & 1 & $\begin{array}{l}25 \\
(14.45)\end{array}$ & $\begin{array}{l}1.91 \\
(1.27 \\
2.87)\end{array}$ & 0.003 \\
\hline Cancer & $\begin{array}{l}39 \\
(10.08)\end{array}$ & $\begin{array}{l}1.06 \\
(0.76 \\
1.48)\end{array}$ & 0.789 & $18(12.6)$ & $\begin{array}{l}1.05 \\
(0.64 ; \\
1.70)\end{array}$ & 0.973 & $21(8.61)$ & $\begin{array}{l}1.03 \\
(0.66 \\
1.62)\end{array}$ & 0.991 \\
\hline Cardiopathy & $\begin{array}{l}4 \\
(11.43)\end{array}$ & $\begin{array}{l}1.20 \\
(0.47 \\
3.04)\end{array}$ & 0.572 & $1(6.67)$ & $\begin{array}{l}0.54 \\
(0.08 \\
3.65)\end{array}$ & 1 & $3(15.0)$ & $\begin{array}{l}1.81 \\
(0.63 \\
5.21)\end{array}$ & 0.232 \\
\hline DM & $\begin{array}{l}19 \\
(9.79)\end{array}$ & $\begin{array}{l}1.02 \\
(0.65 \\
1.60)\end{array}$ & 1 & $6(9.23)$ & $\begin{array}{l}0.74 \\
(0.34 \\
1.63)\end{array}$ & 0.576 & $\begin{array}{l}13 \\
(10.08)\end{array}$ & $\begin{array}{l}1.23 \\
(0.71 ; \\
2.11)\end{array}$ & 0.575 \\
\hline HTA & $\begin{array}{l}44 \\
(9.59)\end{array}$ & $\begin{array}{l}1.00 \\
(0.73 \\
1.37)\end{array}$ & 1 & 19 (11.9) & $\begin{array}{l}0.98 \\
(0.61 ; \\
1.58)\end{array}$ & 1 & $25(8.33)$ & $\begin{array}{l}0.99 \\
(0.65 \\
1.51)\end{array}$ & 1 \\
\hline Kidney failure & $\begin{array}{l}9 \\
(11.84)\end{array}$ & $\begin{array}{l}1.25 \\
(0.67 ; \\
2.33)\end{array}$ & 0.629 & $2(7.41)$ & $\begin{array}{l}0.60 \\
(0.16 \\
2.31)\end{array}$ & 0.638 & $7(14.29)$ & $\begin{array}{l}1.75 \\
(0.86 \\
3.54)\end{array}$ & 0.181 \\
\hline Obesity & $\begin{array}{l}62 \\
(11.76)\end{array}$ & $\begin{array}{l}1.32 \\
(1.00 \\
1.75)\end{array}$ & 0.062 & $22(12.7)$ & $\begin{array}{l}1.06 \\
(0.67 ; \\
1.67)\end{array}$ & 0.899 & $\begin{array}{l}40 \\
(11.30)\end{array}$ & $\begin{array}{l}1.51 \\
(1.06 \\
2.16)\end{array}$ & 0.031 \\
\hline Respiratory disease & $\begin{array}{l}13 \\
(8.44)\end{array}$ & $\begin{array}{l}0.87 \\
(0.51 ; \\
1.49)\end{array}$ & 0.72 & $4(7.84)$ & $\begin{array}{l}0.63 \\
(0.24 \\
1.64)\end{array}$ & 0.449 & $9(8.74)$ & $\begin{array}{l}1.05 \\
(0.55 \\
2.00)\end{array}$ & 1 \\
\hline Smoking & $\begin{array}{l}22 \\
(6.18)\end{array}$ & $\begin{array}{l}0.60 \\
(0.39 \\
0.92)\end{array}$ & 0.022 & $14(13.3)$ & $\begin{array}{l}1.12 \\
(0.65 ; \\
1.91)\end{array}$ & 0.811 & $8(3.19)$ & $\begin{array}{l}0.34 \\
(0.17 \\
0.68)\end{array}$ & 0.002 \\
\hline Antibiotics & $\begin{array}{l}19 \\
(9.74)\end{array}$ & $\begin{array}{l}1.02 \\
(0.65 \\
1.59)\end{array}$ & 1 & $6(8.22)$ & $\begin{array}{l}0.65 \\
(0.29 \\
1.44)\end{array}$ & 0.368 & $\begin{array}{l}13 \\
(10.66)\end{array}$ & $\begin{array}{l}1.30 \\
(0.76 \\
2.24)\end{array}$ & 0.438 \\
\hline Antivirals & $\begin{array}{l}2 \\
(22.22)\end{array}$ & $\begin{array}{l}2.33 \\
(0.68 \\
7.79)\end{array}$ & 0.212 & $0(0.0)$ & Ref & 1 & $2(33.33)$ & $\begin{array}{l}4.02 \\
(1.28 \\
12.64)\end{array}$ & 0.083 \\
\hline
\end{tabular}

* They are represented by $\mathrm{n}$ and percentages.

The reference category for comparison has been the No condition. 


\begin{tabular}{|c|c|c|c|c|c|c|c|c|c|}
\hline & Total & PR & $\begin{array}{l}\mathrm{P} \text { - } \\
\text { value }\end{array}$ & $\begin{array}{l}\text { 1st } \\
\text { Screening }\end{array}$ & PR & $\begin{array}{l}\text { P- } \\
\text { value }\end{array}$ & $\begin{array}{l}\text { 2nd } \\
\text { Screening }\end{array}$ & PR & $\begin{array}{l}\mathrm{P} \text { - } \\
\text { value }\end{array}$ \\
\hline Immunosuppressants & $\begin{array}{l}1 \\
(7.14)\end{array}$ & $\begin{array}{l}0.74 \\
(0.11 ; \\
4.94)\end{array}$ & 1 & $1(25.0)$ & $\begin{array}{l}2.07 \\
(0.37 \\
11.43)\end{array}$ & 0.405 & $0(0.0)$ & - & 1 \\
\hline
\end{tabular}

The seroprevalence was significantly different according to the AMG morbidity index $(p=0.043)$, with an increase from lower to higher AMG index: in AMG of 1, the prevalence was 7.3\%, in AMG of 2, 10.2\%, in AMG of 3,11.1\% and in AMG of 4 , the prevalence was $14.0 \%$ (Table 2). The prevalence of antibodies was also higher in cases with a diagnosis of COVID and contact diagnosis of COVID (Table 2).

The seroprevalence of antibodies against COVID-19 was similar among users with or without a diagnosis of other pathologies, such as cancer, heart disease, diabetes, arterial hypertension, renal failure, obesity or respiratory disease. There was also no difference in antibody seroprevalence between users who took antibiotics, antivirals or immunosuppressants and those who did not. In contrast, users who smoked had a lower prevalence of antibodies than non-smoking users, with a PR = $0.60(0.39,0.92)(p$-value $=0.022)($ Table 2$)$.

The study was conducted in two stages, a first one in October and a second one in December 2020, the period between 15 October and the end of December marked the second wave of COVID cases. The first screening sample was similar to the second screening sample in terms of age, percentage of women, AMG levels and total number of diagnoses. The number of CCPs tested was significantly higher in the first screening ( $p$-value $=0.006)$ in which there was also a higher percentage of users who had been COVID+ in the last 6 months ( $p$-value <0,001) (Table 1).

As for individual diagnoses, only the percentage of cancer showed differences, with a higher percentage in the first sample $(20.7 \%$ vs. $16.5 \%$, p-value $=0.020)($ Table 1$)$.

The seroprevalence of antibodies to COVID-19 was significantly higher in the October analysis $12.16 \% \mathrm{CI} 95: 9.93 ; 14.80$, than in the December analysis 8.38\% Cl95: 7.01;9.91 (Table 2).

In the October screening, no statistically significant associations were observed between the factors analysed and the detection of COVID-19 antibodies, except for the positive relationship between those who had undergone COVID-19 six months earlier and the positive antibody result. In contrast, in the second screening, a significant association was detected between antibody prevalence and categorized age, origin, obesity, smoking and having been COVID-19 positive or close contact in the last 6 months (Table 2).

\section{Discussion}

Vilanova del Camí is a municipality that makes up the Conca de Ódena. Conca d'Ódena was considered to be ground zero of the pandemic at state level ${ }^{3}$. This is the first study to analyse the presence of antibodies against COVID in this area. The seroprevalence of antibodies in the population analysed was $9.6 \%$, a value higher than the seroprevalence of $7 \%$ described in the Barcelona region ${ }^{11}$. The results of this study show the great impact of the first wave of COVID in the region. If we consider only the analysis of the first wave, the prevalence amounts to $12.16 \%$. To date, the impact on a municipality in the region had not been demonstrated; in fact, in March 2020 COVID cases were not diagnosed with tests, but were considered suspicions. Although no official mortality data per municipality are available for 2020 , the written press and data from the local funeral home, established an approximate increase in mortality of $386 \%$, therefore the real seroprevalence could be much higher. 
The seroprevalence by gender was similar, as noted in some studies ${ }^{12}$. In contrast, a significantly higher prevalence was observed in the over-60 age group than in the younger age groups. These results could confirm the suspicion of the high impact of the first wave in older people, in fact, the prevalence in CCP $(14.29 \%)$ and ACD (25\%) was higher than the population without CCP or ACD condition.

The AMG of the Vilanova del Camí population was similar to that observed in the screened population. The prevalence ratio showed that a high AMG $(A M G=4)$ is a risk factor for having suffered from COVID. The AMG $^{16}$ Index is a morbidity grouper that allows stratification of populations. Therefore, the higher the population morbidity, the higher the risk of having suffered from COVID and therefore of having antibodies.

It has been described that in populations with lower socio-economic levels, the impact of COVID is greater than in higher socio-economic levels ${ }^{17-19}$. The population of Vilanova del Camí has a high prevalence of antibodies (above the average for Barcelona and Spain) and has a low socio-economic index. Therefore, it corresponds with other studies, which consider that there are more problems in performing isolations and quarantines correctly in close contacts.

Analysis of diagnoses and seroprevalence only revealed that obesity could be a risk factor for having a higher seroprevalence of antibodies against COVID. Several studies have shown that obesity is a risk factor for developing the disease and for developing a more severe coronavirus disease ${ }^{20,21}$. It should be noted that this increased risk is for all ages. Obesity is an important public health problem. In the present study, $24.3 \%$ of the screened users were obese, a high figure, which is also related to populations with a low socio-economic level.

Other risk factors were also analysed, such as the prescription of antivirals or immunosuppressants, but very few cases of users with an active prescription of these drugs were observed in the sample analysed.

The study was conducted in two months (October and December). The population between the first and second screening was similar (Table 1). It should be noted that in October a higher seroprevalence was detected than in December. These results could be explained by the fact that in October a higher number of COVID diagnoses were observed in the 6 months prior to the test population than in December, showing again the great impact of the first peak in Conca d'Ódena. In addition, it should be noted that antibodies against COVID decrease over time $22-24$.

Interestingly the first screening did not detect risk factors for seroprevalence, on the contrary in December they did observe factors previously described in the literature, age, country of origin, obesity and smoking. This difference in risk factors in the two periods of analysis could be explained by the fact that in December the behaviour of COVID in Vilanova del Camí was more similar to other territories, unlike in October when the effects of the first wave were carried over and where the mortality rate was higher.

Health and non-health professionals from all areas (nursing homes, primary care, social and health care and hospitals) who experienced the first wave of the pandemic in the Conca d'Ódena, are the true witnesses of the struggle that took place during the first month and in their minds will remain the magnitude of the moments lived and suffered, always surrounded by uncertainty.

\section{Conclusions}

The real impact of the first wave of the pandemic will never be known, due to the initial lack of diagnostic tests, high mortality and the fact that antibodies decay over time. This study demonstrates the high seroprevalence of antibodies in the pandemic epicentre of Catalonia. In October 2020, $12.16 \%$ of the population had antibodies against COVID and in December 2020, 8.38\%. Risk factors associated with positive seroprevalence were age, AMG index, COVID diagnosis and contact diagnosis. Obesity was also a risk factor for a positive seroprevalence in the December screening. These results show the real impact of the first wave of COVID in Conca d'Ódena. 


\section{Methods}

Observational, descriptive, cross-sectional study. The reference population of the study was all the residents of the municipality of Vilanova del Camí. The study population was the resident population of Vilanova del Camí who voluntarily attended the open call for serological screening for Covid-19 antibodies, as a result of a collaboration between the Vilanova del Camí Town Council, the primary care centre of the Catalan Health Institute of Vilanova del Camí and the August Pi i Sunyer Biomedical Research Institute (IDIBAPS). The inclusion criteria for serology were being a resident in the municipality of Vilanova del Camí, being older than 1 year and accepting the informed consent. The only exclusion criterion for serology was the presence of symptoms compatible with active COVID19 infection.

The municipality of Vilanova del Camí has 12361 inhabitants, and 3610 participated in the screening from which a random sample of 2170 individuals was selected to estimate, with a confidence of $95 \%$ and a precision of $+/-1$ percentage units, a prevalence expected to be around $7 \%^{10}$. This sample was selected from the register of participants in the primary care centre diaries, eliminating duplicate users and expecting $5 \%$ of necessary replacements.

The rapid serological test to determine the presence of antibodies against COVID-19 was Salocor (Salofa Oy), with a sensitivity of $93.7 \%$ and a specificity of $99.9 \%$ to detect IgG. The antibody result (IgG) was recorded in the corresponding variable of the Primary Care Clinical Station. The variables analysed in the study were obtained from the existing clinical history of the users: sex, age, diagnosis of COVID19, close contact with COVID-19 during the 6 months prior to the date of the test, origin of the population (native/migrant), prescription of immunosuppressants or antivirals or antibiotics in the last month of the test. The registry of diagnoses of arterial hypertension, diabetes mellitus, chronic respiratory disease (bronchial asthma or COPD), chronic renal failure, cancer, obesity, heart disease and smoking were also analysed. In addition, the conditions of Complex Chronic Patient (CCP), of patient with Advanced Chronic Disease (ACD) and the AMG index were considered $^{25}$.

A univariate analysis of qualitative variables (absolute frequency and percentage) and quantitative variables (mean and standard deviation or median and quartiles, according to normality distribution) was performed. Bivariate studies of the dependent variables and the independent variables were also carried out. The prevalence of the total sample was calculated, and the prevalence ratio was estimated according to the potential variables, to estimate the magnitude of association. Statistically significant differences were considered statistically significant with p-values of $<0.05$, and $95 \%$ confidence intervals. All analyses were performed with version 5.3.2 of the statistical program R.

The study has the approval of the Ethics Committee from the Foundation University Institute for Primary Health Care Research Jordi Gol i Gurina (IDIAPJGol) (21/136-PCV) and all participants signed informed consent forms. This study was conductes in accordance with the latest revised ethical guidelines of the Declaration of Helsinki.

\section{Declarations}

\section{Acknowledgements}

August Pi i Sunyer Biomedical Research Institute (IDIBAPS), Hospital Clínic, Vilanova del Camí Town Council, health professionals participating in the project and the entire population of the municipality.

\section{Author Contribution}

SM: devising and design of the study, data collection, writing of the article. Review and discussion

QM: analysis and interpretation of the data, writing of the article, approval of the final version for publication. Review and discussion

AS: data collection, critical review, approval of the final version for publication. Review and discussion

Page $10 / 12$ 
MG: data collection, critical review, approval of the final version for publication. Review and discussion

$\mathrm{MH}$ : analysis and interpretation of the data, writing of the article, approval of the final version for publication. Review and discussion

MJG: devising and design of the study, analysis and interpretation of the data, writing of the article, approval of the final version for publication. Review and discussion

\section{References}

1. Zhu, N. et al. A Novel Coronavirus from Patients with Pneumonia in China, 2019. N. Engl. J. Med. 382, 727-733 (2020).

2. European Centre for Disease Prevention and Control. Available at: https://www.ecdc.europa.eu/en/covid-19.

3. Sanidad, M. de. Boletón Oficial del Estado. Boletín Of. del Estado 28352-28353 (2020).

4. Tracking - Johns Hopkins Coronavirus Resource Center. (2021). Available at: https://coronavirus.jhu.edu/map.html.

5. To, K. K. W. et al. Temporal profiles of viral load in posterior oropharyngeal saliva samples and serum antibody responses during infection by SARS-CoV-2: an observational cohort study. Lancet Infect. Dis. 20, 565-574 (2020).

6. Rostami, A. et al. SARS-CoV-2 seroprevalence worldwide: a systematic review and meta-analysis. Clin. Microbiol. Infect. 27, 331-340 (2021).

7. Lai, C. C., Wang, J. H. \& Hsueh, P. R. Population-based seroprevalence surveys of anti-SARS-CoV-2 antibody: An up-to-date review. Int. J. Infect. Dis. 101, 314-322 (2020).

8. Venugopal, U. et al. SARS-CoV-2 seroprevalence among health care workers in a New York City hospital: A cross-sectional analysis during the COVID-19 pandemic. Int. J. Infect. Dis. 102, 63-69 (2021).

9. Landa, V., Garcia, J. Á., Moyano, M. \& Molina, B. Prevención primaria del duelo complicado: atención al paciente y su familia en el final de la vida y muerte/perimuerte. Fisterra (2017).

10. Eckerle, I. \& Meyer, B. SARS-CoV-2 seroprevalence in COVID-19 hotspots. Lancet 396, 514-515 (2020).

11. Pollán, M. et al. Prevalence of SARS-CoV-2 in Spain (ENE-COVID): a nationwide, population-based seroepidemiological study. Lancet 396, 535-544 (2020).

12. Vena, A. et al. Prevalence of Antibodies to SARS-CoV-2 in Italian Adults and Associated Risk Factors. J. Clin. Med. 9, 2780 (2020).

13. Rogawski McQuade, E. T. et al. Assessment of Seroprevalence of SARS-CoV-2 and Risk Factors Associated With COVID19 Infection Among Outpatients in Virginia. JAMA Netw. open 4, e2035234 (2021).

14. Costa, S. F. et al. Severe Acute Respiratory Syndrome Coronavirus 2 (SARS-CoV-2) Seroprevalence and Risk Factors Among Oligo/Asymptomatic Healthcare Workers: Estimating the Impact of Community Transmission. Clin. Infect. Dis. 2, $1-5$ (2020).

15. Vos, E. R. A. et al. Nationwide seroprevalence of SARS-CoV-2 and identification of risk factors in the general population of the Netherlands during the first epidemic wave. J. Epidemiol. Community Health 1-7 (2020). doi:10.1136/jech-2020215678

16. Álvarez, D. et al. INFORMES CIENTíFICOS COVID-19 Coordinador: José Alcamí Pertejo. (2020).

17. Little, C. et al. The Impact of Socioeconomic Status on the Clinical Outcomes of COVID-19; a Retrospective Cohort Study. J. Community Health 46, 794-802 (2021).

18. Colls, C., Mias, M. \& García-Altés, A. A deprivation index to reform the financing model of primary care in Catalonia (Spain). Gac. Sanit. 34, 44-50 (2020).

19. Domínguez-Berjón, M. F. et al. Construcción de un índice de privación a partir de datos censales en grandes ciudades españolas (Proyecto MEDEA). Gac. Sanit. 22, 179-187 (2008). 
20. Petrova, D. et al. La obesidad como factor de riesgo en personas con COVID-19: posibles mecanismos e implicaciones. Atención Primaria 52, 496-500 (2020).

21. Stefan, N., Birkenfeld, A. L., Schulze, M. B. \& Ludwig, D. S. Obesity and impaired metabolic health in patients with COVID19. Nat. Rev. Endocrinol. 16, 341-342 (2020).

22. Iyer, A. S. et al. Persistence and decay of human antibody responses to the receptor binding domain of SARS-CoV-2 spike protein in COVID-19 patients. Sci. Immunol. 5, 1-12 (2020).

23. Isho, B. et al. Persistence of serum and saliva antibody responses to SARS-CoV-2 spike antigens in COVID-19 patients. Sci. Immunol. 5, 1-20 (2020).

24. Madewell, Z. J., Yang, Y., Jr, I. M. L., Halloran, M. E. \& Dean, N. E. NOTE: This preprint reports new research that has not been certified by peer review and should not be used to guide clinical practice. 1. medRxiv 6, 1-13 (2020).

25. Monterde, D., Vela, E. \& Clèries, M. Los grupos de morbilidad ajustados: nuevo agrupador de morbilidad poblacional de utilidad en el ámbito de la atención primaria. Atención Primaria 48, 674-682 (2016).

\section{Figures}

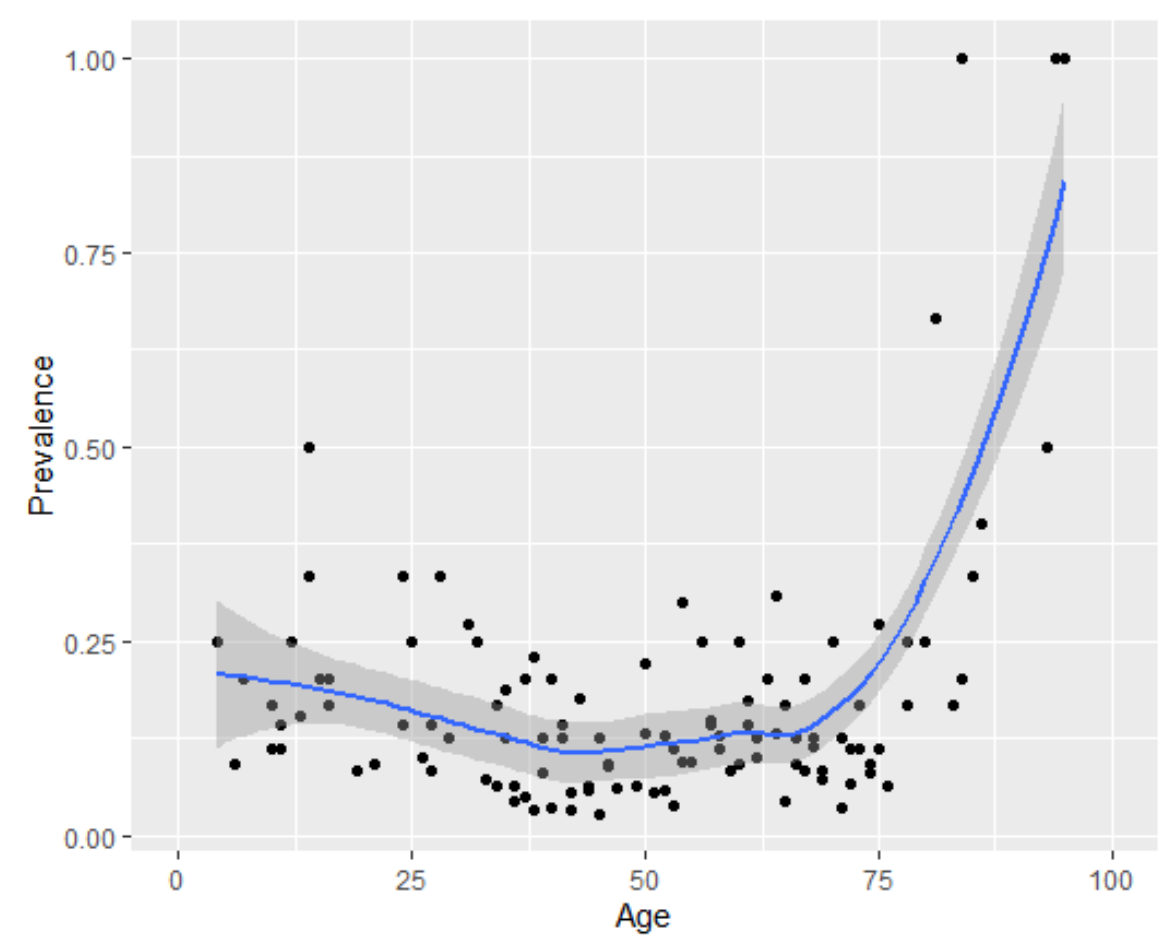

Figure 1

Relation between SARS-CoV-2 antibody seroprevalence and age 